\title{
Morphology and disaccharidase activity of small intes- tinal mucosa in post-weaning-induced malnourished rats and after realimentation
}

\author{
Rustadi Sosrosumihardjo, Agus Firmansyah, Asri Rasad, Daldiyono Harjodisastro, Endi Ridwan, \\ Septilia Inawati Wanandi, Dwirini Retno
}

\begin{abstract}
Background The most common cause of failure to thrive in infants is malnutrition which causes histological and biochemical changes of small intestine. Studies on histology and enzyme activity of small intestinal mucosa were not much developed.

Objective To study about histology and disaccharidases activity of small intestinal mucosa in post-weaning-induced malnourished rats. Methods We used Sprague-Dawley white rats as the subjects of this study with post test-control group design. The study was performed at the CentER for Research of Food and Nutrition Development from April 2003 to December 2004.

Results There were a decrease of body weight (hypotrophy normoblastic) and an increase of disaccharidase activity of small intestinal mucosa in post-weaning-induced malnourished rats. After realimentation, there were an increase of body weight, an improvement of the hypotrophy, and a decrease of the enzyme but they still cannot reach normal condition.

Conclusion In malnourished rats, there are decrease of body weight hypotrophy normoblastic and increase of disaccharidases activity of intestinal mucosa that are improved after realimentation

[Paediatr Indones 2006;46:229-235].
\end{abstract}

Keywords: small intestinal mucosa, disaccharidase activity, post-weaning-induced malnutrition, realimentation.

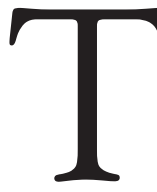
he most common etiology of failure to thrive in infants is malnutrition that causes gastrointestinal disorders, particularly nutrient maldigestion and malabsorption, and chronic diarrhea. ${ }^{1,2}$ Malnutrition also causes immunity impairment of small intestinal mucosa. ${ }^{1,3}$
Malnutrition occurring in children of 1 year of age may cause growth disorder, that can be seen in children of 5 years of age as stunted child. ${ }^{4}$ When growth disorder occurs in a girl and continues until grown up, she will be a malnourished woman. ${ }^{4,5} \mathrm{Mal}$ nourished mother will deliver low birth weight infants, as a result of intrauterine growth retardation. ${ }^{4,6}$ Low birth weight infants have higher risk of morbidity and mortality due to diarrhea 3-4 times more frequent than that of normal birth weight infants. ${ }^{4,6}$

Malnutrition can be recovered by adequate and balanced nutrition. In malnourished infants, realimentation can be given by calculating energy required to achieve the ideal growth. ${ }^{7}$ Cook's study ${ }^{8}$ proved that realimentation recovered histology and biochemistry changes of gastrointestinal tract. After that, study on morphology and biochemistry was not much developed, especially about small intestinal en-

From the Department of Clinical Pathology (RS), Child Health (AF), Biochemistry and Biomoleculer (AR, SIW, DR), Internal Medicine (DH), Medical School, University of Indonesia, Jakarta, Indonesia; Center for Research and Development of Food Nutrition (ER), Bogor, Indonesia.

Reprint requests to: Rustadi Sosrosumiharjo, MD, Department of Clinical Pathology, Medical School, University of Indonesia, Cipto Mangunkusumo Hospital, Jl. Salemba 6, Jakarta, Indonesia. Tel. 62-213142265/62-21-3143707. Fax.62-21-3147713.Email: kfkui@cbn.net.id. 
zyme activity in malnutrition. Based on this background, the authors conducted a study on the morphology and disaccharidases activity of small intestinal mucosa in post-weaning-induced malnutrition and after realimentation, by using experimental animal.

\section{Methods}

This was an experimental study using white rats Sprague-Dawley with post test-control group, performed at Center for Research and Development of Food and Nutrition, Bogor, from April 2003 to December 2004. Forty male litters of 8 weeks old which born to 5 female rats weighing 250-300 grams, were fed with standard laboratory diet containing complete nutrition with total of food calorie of 378 calorie/100 gram of food.

To obtain post-weaning-induced malnourished rats group, malnutrition induction had been done by diet restriction, i.e. $50 \%$ of the control intake. Control rats group was given food ad libitum. This post-weaning-induced malnutrition started right after weaning, at the age of 3 weeks to 12 weeks old. ${ }^{9,10}$ Realimentation was done 8 weeks after the end of induction period, to rats at the age of 12 weeks to 20 weeks old. At realimentation period, one of control rats group continued to get food ad libitum; one of post-weaning-induced malnourished rats group was not realimented, but continued to have diet restriction; and one of post-weaning-induced malnourished rats was realimented, with food given ad libitum. According to Frederer formula, ${ }^{11}$ each group should contain a minimum of 5 rats; we used 8 rats per group in our study.

At the end of post-weaning-induced malnourished period, one of control rats group and one of malnourished rats group were sacrified to obtain data of post-weaning-induced malnutrition. At the end of realimentation period one of post-weaning-induced malnourished rats group which realimented were sacrified, one of post-weaning-induced malnourished rats which also not realimented, and one of control rats group were sacrified to obtain data of post-weaning-induced malnutrition after realimentation.

Data including body weight, other physical parameters (length, weight/length ratio), serum albumin level, small intestinal parameters (weight, length, diameter, mucosa weight); were collected by Centre for
Research and Development of Food and Nutrition, Bogor. The examination of histology of mucosa (mucosa thickness, villus height, cryptus depth, ratio villus/crypta, number of villus), was performed at Veterinology Research Unit, Bogor. Serum albumin level was measured at Department of Clinical Pathology, Medical School, University of Indonesia. The determination of protein content, DNA content, protein/DNA ratio, disaccharidase activity of small intestinal mucosa were performed at Department of Biochemistry and Biomolecular, Medical School, University of Indonesia.

Morphology of small intestinal mucosa was evaluated by morphometry. Disaccharidases activity was measured by modification of Dahlqvist method. Homogenation of small intestinal mucosa tissue which had been prepared in distilled water was incubated in suitable substrate, i.e. lactase, maltase, and sucrase to hydrolyse the disaccharide. ${ }^{12}$ Glucose which is formed was measured quantitatively using glucose peroxidase.

\section{Results}

It was found that post-weaning-induced malnourished rats had lower body weight, serum albumin level, physical parameters, and small intestinal parameters than those of controls (Table 1).

Body weight and other parameters of realimented post-weaning-induced malnourished rats were higher than those of non-realimented rats but lower than those of control rats (Table 2).

Four weeks after realimentation, body weight of realimented post-weaning-induced malnourished rats was higher than that of non realimented rats, but at the end of realimentation ( 20 weeks old) it could not reach body weight of control rats (Figure 1).

Serum albumin level of post-weaning-induced malnourished rats after realimentation was higher than that of post-weaning-induced malnourished rats before realimentation (Figure 2).

Small intestinal mucosa of post-weaning-induced malnourished rats was hypotrophy and normoplasy (Table 3). Hypotrophy was confirmed based on mucosa thickness, villus height, and cryptus depth which were lower than control. This finding was also confirmed by a decrease of protein content and protein/ DNA ratio. Normoplasy was confirmed based on DNA 
Rustadi Sosrosumihardjo et al: Morphology and disaccharidase activity of small intestinal mucosa in malnourished rats

TABLE 1. BOdY WEIGHT ${ }^{*}$, OTHER PHYSICAL PARAMETERS ${ }^{*}$, SERUM ALBUMIN LEVEL ${ }^{*}$, AND SMALL INTESTINAL PARAMETERS* ${ }^{*}$ OF POST-WEANING-INDUCED MALNOURISHED RATS (12 WEEKS OLD)

\begin{tabular}{lcc}
\hline Parameters & $\begin{array}{c}\text { Control } \\
(\mathbf{n}=8)\end{array}$ & $\begin{array}{c}\text { Malnutrition } \\
(\mathbf{n}=8)\end{array}$ \\
\hline Body weight(g) & $213.0 \pm 19.7$ & $148.6 \pm 14.0^{\mathrm{a}}$ \\
Serum albumin level $(\mathrm{mg} / \mathrm{dl})$ & $4.56 \pm 0.28$ & $4.19 \pm 0.12^{\mathrm{a}}$ \\
Body length $(\mathrm{cm})$ & $20.1 \pm 1.0$ & $17.9 \pm 0.9^{\mathrm{a}}$ \\
Body weight/length $(\mathrm{g} / \mathrm{cm})$ & $10.6 \pm 0.6$ & $8.3 \pm 0.5^{\mathrm{a}}$ \\
Chest circumstance $(\mathrm{cm})$ & $30.6 \pm 0.9$ & $22.9 \pm 1.8^{\mathrm{a}}$ \\
Small intestinal weight $(\mathrm{g})$ & $6.9 \pm 0.6$ & $5.7 \pm 0.8^{\mathrm{a}}$ \\
Small intestinal length $(\mathrm{cm})$ & $119.7 \pm 3.7$ & $105.3 \pm 8.6^{\mathrm{a}}$ \\
Small intestinal diameters $(\mathrm{mm})$ & $3.0 \pm 0.2$ & $2.3 \pm 0.1^{\mathrm{a}}$ \\
Small intestinal mucosa weight $(\mathrm{mg})$ & $2431.7 \pm 363.7$ & $1840.1 \pm 590.8^{\mathrm{a}}$ \\
\hline
\end{tabular}

* Presented as mean and standard deviation.

a $t$ test significantly different $(P<0.05)$ from control

Table 2. Physical parameters* ${ }^{*}$, Small intestinal Parameters* ${ }^{*}$ POSt-weaning-induced malnutrition afTER REALIMENTATION (20 WEEKS OLD)

\begin{tabular}{lccc}
\hline Parameters & $\begin{array}{c}\text { Control } \\
(\mathbf{n}=\mathbf{8})\end{array}$ & $\begin{array}{c}\text { Malnutrition } \\
(\mathbf{n}=\mathbf{8})\end{array}$ & $\begin{array}{c}\text { Realimentation } \\
(\mathbf{n}=\mathbf{8})\end{array}$ \\
\hline Body weight $(\mathrm{g})$ & $355.7 \pm 17.2$ & $200.3 \pm 1.6$ & $293.1 \pm 21.5^{\mathrm{a}, \mathrm{c}}$ \\
Body length $(\mathrm{cm})$ & $22.7 \pm 0.5$ & $20.2 \pm 0.5$ & $21.9 \pm 0.7^{\mathrm{a}, \mathrm{c}}$ \\
Body weight/length $(\mathrm{g} / \mathrm{cm})$ & $15.7 \pm 0.5$ & $9.9 \pm 0.2$ & $13.4 \pm 0.6^{\mathrm{a}, \mathrm{c}}$ \\
Chest circumstance $(\mathrm{cm})$ & $38.9 \pm 1.2$ & $24.3 \pm 1.2$ & $31.1 \pm 0.7^{\mathrm{a}, \mathrm{c}}$ \\
Small intestinal weight(g) & $8.6 \pm 0.7$ & $4.9 \pm 0.4$ & $7.4 \pm 1.0^{\mathrm{a} . \mathrm{c}}$ \\
Small intestinal length $(\mathrm{cm})$ & $129.5 \pm 7.5$ & $111.5 \pm 4.8$ & $124.4 \pm 11.0^{\mathrm{a} . \mathrm{c}}$ \\
Small intestinal diameter $(\mathrm{mm})$ & $3.2 \pm 0.1$ & $2.2 \pm 0.1$ & $2.7 \pm 0.2^{\mathrm{a} . \mathrm{c}}$ \\
Small intestinal mucosa weight $(\mathrm{mg})$ & $207.9 \pm 183.7$ & $1935.3 \pm 308.1$ & $2709.6 \pm 390.2^{\mathrm{a} . c}$ \\
\hline
\end{tabular}

* Presented as mean \pm standard deviation.

a t test significantly different $(P<0.05)$ from control.

${ }^{c} t$ test significantly different $(P<0.05)$ from malnutrition.

Body weight are presented as mean \pm standard deviation

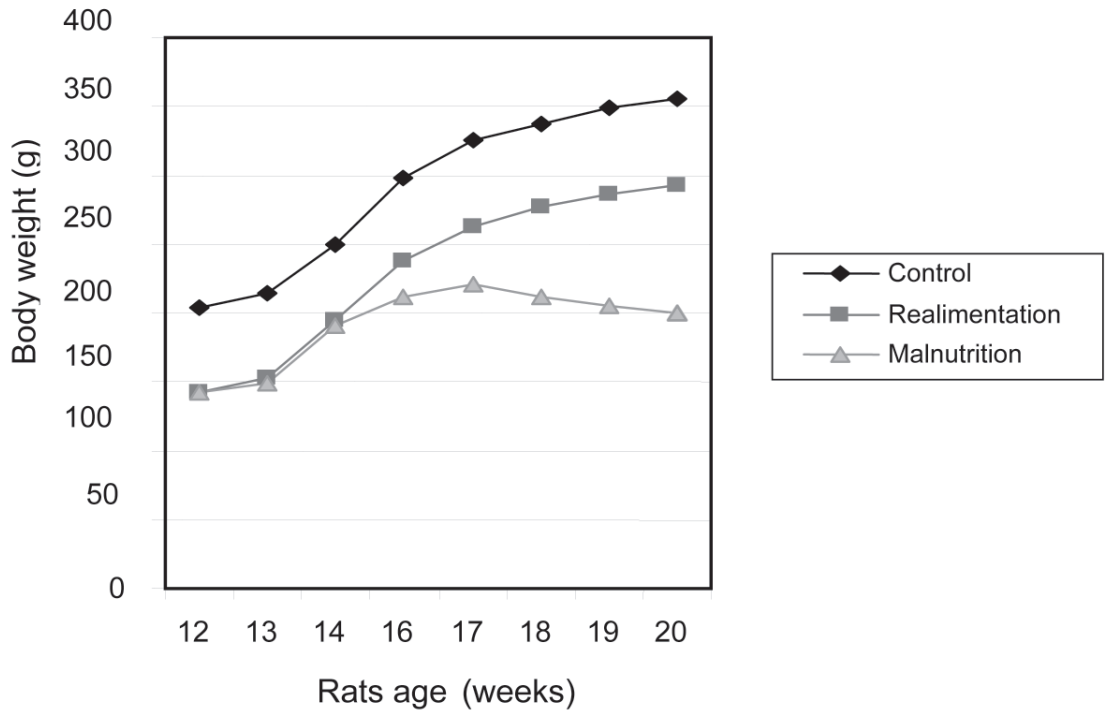

Figure 1. THE INCREASE OF REALIMENTATION BODY WEIGHT POST-WEANING-INDUCED MALNUTRITION FROM 12 WEEKS TO 20 WEEKS. 


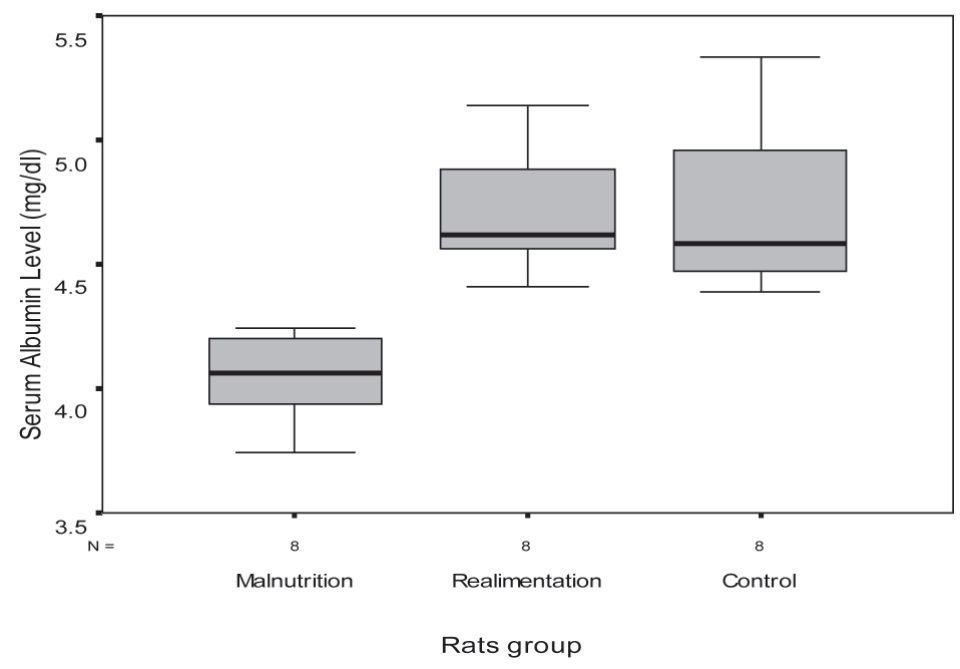

Figure 2. Serum albumin LeVEL of Post-WEaning-InduCED MaLNUTRITION AND THAT AFTER REALIMENTATION.

Table 3. Mucosa Parameters*, PROTEIn CONTENT*, AND SMALL INTESTINAL MUCOSA DNA* POST-WEANING-INDUCED MALNUTRITION AFTER REALIMENTATION (20 WEEKS OLD)

\begin{tabular}{lcc}
\hline Parameters & $\begin{array}{c}\text { Control } \\
(\mathbf{n}=8)\end{array}$ & $\begin{array}{c}\text { Malnutrisi } \\
(\mathbf{n}=\mathbf{8})\end{array}$ \\
\hline Mucosa thickness $(\mu \mathrm{m})$ & $688.1 \pm 109.2$ & $455.7 \pm 37.2^{\mathrm{a}}$ \\
Villus height $(\mu \mathrm{m})$ & $431.3 \pm 47.5$ & $299.4 \pm 36.0^{\mathrm{a}}$ \\
Cryptus depth $(\mu \mathrm{m})$ & $183.1 \pm 26.5$ & $110.6 \pm 16.4^{\mathrm{a}}$ \\
Ratio villus/cryptus & $2.4 \pm 0.4$ & $2.7 \pm 0.4^{\mathrm{b}}$ \\
Number of villus $($ per mm) & $9.1 \pm 0.8$ & $9.50 .3^{\mathrm{b}}$ \\
Protein content $(\mathrm{mg})$ & $610.0 \pm 85.5$ & $435.6 \pm 139.7^{\mathrm{a}}$ \\
DNA content $(\mathrm{mg})$ & $44.9 \pm 18.7$ & $50.0 \pm 11.7^{\mathrm{b}}$ \\
Ratio protein/DNA & $15.7 \pm 6.3$ & $8.6 \pm 1.3^{\mathrm{a}}$ \\
\hline
\end{tabular}

* Presented as mean \pm standard deviation.

a t test significantly different $(p<0.05)$ from control.

$\mathrm{b} t$ test not significantly different $(p>0.05)$ from control. content of small intestinal mucosa that remained unchanged compared to control.

After realimentation, there was a recovery of small intestinal mucosa growth but it could not reach the growth of control rats (Table 4).

Disaccharidase spesific activity of small intestinal mucosa of post-weaning-induced malnourished rats was higher than that of control (Table 5).

After realimentation, disaccharidase spesific activity of post-weaning-induced malnourished rats was lower than that of non-realimented post-weaning-induced malnourished rats, but it was higher than that of control rats (Table 6).

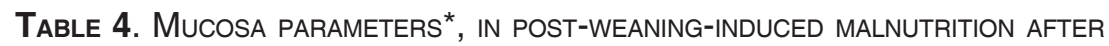
REALIMENTATION (20 WEEKS OLD)

\begin{tabular}{lccc}
\hline $\begin{array}{l}\text { Mucosa } \\
\text { parameters }\end{array}$ & $\begin{array}{c}\text { Control } \\
(\mathbf{n}=\mathbf{8})\end{array}$ & $\begin{array}{c}\text { Malnutrition } \\
(\mathbf{n}=\mathbf{8})\end{array}$ & $\begin{array}{c}\text { Realimentation } \\
(\mathbf{n}=\mathbf{8})\end{array}$ \\
\hline Mukosa thickness $(\mu \mathrm{m})$ & $995.0 \pm 219.1$ & $433.8 \pm 38.3$ & $485.6 \pm 46.8^{\mathrm{a}, \mathrm{c}}$ \\
Villus depth $(\mu \mathrm{m})$ & $451.0 \pm 88.9$ & $303.8 \pm 54.4$ & $386.9 \pm 33.3^{\mathrm{a}, \mathrm{c}}$ \\
Cryptus depth $(\mu \mathrm{m})$ & $198.5 \pm 53.1$ & $93.8 \pm 15.1$ & $153.8 \pm 10.3^{\mathrm{a}, \mathrm{c}}$ \\
Ratio villus/cryptus & $2.3 \pm 0.3$ & $3.3 \pm 0.8$ & $2.6 \pm 0.3^{\mathrm{b}, \mathrm{d}}$ \\
Number of vilus (per mm) & $8.8 \pm 0.5$ & $9.9 \pm 0.7$ & $9.3 \pm 0.7^{\mathrm{b}, \mathrm{d}}$ \\
Protein content $(\mathrm{mg})$ & $936.6 \pm 50.5$ & $484.8 \pm 74.3$ & $773.4 \pm 97.7^{\mathrm{a}, \mathrm{c}}$ \\
DNA content $(\mathrm{mg})$ & $39.7 \pm 10.7$ & $44.0 \pm 16.8$ & $48.6 \pm 6.8^{\mathrm{b}, \mathrm{d}}$ \\
Ratio protein/DNA & $25.0 \pm 6.1$ & $12.3 \pm 4.0$ & $16.1 \pm 2.2^{\mathrm{a}, \mathrm{c}}$ \\
\hline
\end{tabular}

\footnotetext{
* Presented as mean \pm standard deviation.

a t test significantly different $(\mathrm{P}<0.05)$ from control.

$b_{t} t$ test not significantly different $(P>0.05)$ from control.

${ }^{c} t$ test significantly different $(P<0.05)$ from malnutrition.

${ }^{d}$ t test not significantly different $(P>0.05)$ from malnutrition.
} 
Rustadi Sosrosumihardjo et al: Morphology and disaccharidase activity of small intestinal mucosa in malnourished rats

TABLE 5. DISACCHARIDASE SPESIFIC ACTIVITY* IN POST-WEANING-INDUCED MALNOURISHED RATS (12 WEEKS OLD)

\begin{tabular}{lcc}
\hline Parameters & $\begin{array}{c}\text { Control } \\
(\mathbf{n}=\mathbf{8})\end{array}$ & $\begin{array}{c}\text { Malnutrition } \\
(\mathbf{n}=\mathbf{8})\end{array}$ \\
\hline Lactase $^{* *}$ & $34.7 \pm 5.3$ & $92.8 \pm 23.3^{\mathrm{a}}$ \\
Maltase $^{\star *}$ & $609.9 \pm 33.6$ & $997.0 \pm 111.5^{\mathrm{a}}$ \\
Sucrase $^{* *}$ & $53.9 \pm 6.7$ & $109.42 \pm 23.2^{\mathrm{a}}$ \\
\hline
\end{tabular}

* Presented as mean+stantard deviation.

${ }^{* *}$ Activity in imol/menit/g mucosa.

${ }^{a} t$ test significantly different $(\mathrm{P}<0.05)$ from control. possible mechanism is the development of small intestinal mitochondria epithel anomali caused by malnutrition, resulting energy forming process disorder. This study found that there was a hypotrophy of small intestinal tissue in post-weaning-induced malnourished rats. Different findings was found by Butzner and Gall. ${ }^{18}$ They used rabbit as experiment animal and expanded litter technique as malnutrition induction method. They found protein content and DNA

TABLE 6. DISACCHARIDASE SPESIFIC ACTIVITY* IN POST-WEANING-INDUCED MALNOURISHED RATS AFTER REALIMENTATION (20 WEEKS OLD)

\begin{tabular}{lccc}
\hline Parameters & $\begin{array}{c}\text { Control } \\
(\mathbf{n}=\mathbf{8})\end{array}$ & $\begin{array}{c}\text { Malnutrition } \\
(\mathbf{n}=8)\end{array}$ & $\begin{array}{c}\text { Realimentation } \\
(\mathbf{n}=\mathbf{8})\end{array}$ \\
\hline Lactase $^{* *}$ & $36.3 \pm 11.7$ & $102.3 \pm 18.7$ & $65.9 \pm 8.1^{\text {a.c }}$ \\
Maltase** $^{* *}$ & $584.1 \pm 61.5$ & $1027.9 \pm 181.3$ & $732.5 \pm 68.4^{\text {a.c }}$ \\
Sucrase $^{\star *}$ & $52.6 \pm 3.0$ & $110.1 \pm 31.3$ & $76.0 \pm 8.0^{\text {a.c }}$ \\
\hline
\end{tabular}

* Presented as mean \pm standard deviation.

** Activity in ìmol/menit/g mucosa.

a t test significantly different $(P<0.05)$ from control.

${ }^{c} t$ test significantly different $(P<0.05)$ from malnutrition.

\section{Discussion}

Malnourished rats which was defined as body weight equal or less than $70 \%$ from normal rats were used because most studies used malnutrition rats weighing around $40-70 \%$ from body weight control rats. There are various malnutrition induced techniques used in previous studies, i.e. uterine blood reduction, ${ }^{13}$ low protein diet, ${ }^{14}$ diet restriction, ${ }^{9,15}$ and expanded litter technique. ${ }^{16,17}$ In this study we used diet restriction.

This study found a decrease of body weight, a decrease of other physical parameters, small intestinal parameters, and serum albumin level in malnourished rats. After realimentation the increase of body weight was also paralel with the increase of other parameters.

Similar results were found by Butzner and Gall, ${ }^{18}$ using rabbit as experimental animal. They used expanded litter technique. Realimentation at lactation period was able to increase body weight of rats, but it could not reach normal body weight.

In this study the increase of body weight of realimented rats at 17 weeks was more slowly than at 12-16 weeks. Possible mechanism is that pancreas function disorder started at that age because of malnutrition, resulting nutrient malabsorption, and finally causes more slowly increase of body weight. Another content reduction, it means that malnutrition affects small intestinal mucosa in size as well as in number of cells. Assuming that malnutrition induction using expanded litter technique has the same effect with diet restriction methods, the possibility of why the result was different was due to the difference of the experimental animals.

In post-weaning-induced malnourished rats after realimentation, there was an improvement of small intestinal hypotrophy, but it could not reach normotrophy. This study found that disaccharidases specific activity in post-weaning-induced malnourished rats was higher than that of control rats. Different results were reported by Jambunathan et al $;{ }^{19}$ they found no difference with that of control rats.

Lactase, maltase, and sucrase specific activities of post-weaning-induced malnourished rats, which were higher than control rats, were not parallel with the reduction of villus length. Perhaps there was intestinal adaptation mechanism in malnutrition.

In post-weaning-induced malnourished rats after realimentation there were reduction of disaccharidases activity, lactase, maltase, also disaccharidases, even though it could not reach the control value.

The findings of morphology and disaccharidases activity in post-weaning-induced malnourished rats and 
after realimentation, provide contribution to malnutrition prevention effort by giving realimentation for children to prevent small intestinal mucosa morpho logy and biochemistry disorders caused by malnutrition.

We concluded that in malnourished rats, there is a reduction of body weight, small intestinal mucosa hypotrophy normoplastic, and an increase of disaccharidases activity. In post-weaning-induced malnourished rats after realimentation, there is an increase of body weight but it cannot reach normal, an improvement of small intestinal mucosa hypotrophy but it cannot reach normotrophy, and a reduction of disaccharidases activity but it cannot reach normal value. It is assumed that realimentation is able to improve small intestinal mucosa growth optimally in postweaning-induced malnourished rats.

\section{Acknowledgments}

The authors are grateful to Drh. Cornelis for her assistance in animal experiments method; dr. Vera Damayanti, SpPA(K) for her assitance to evaluate histopathology slides; and dr. Sofiudin, SKM for his assitance to analyze statistics. To Drug and Food Administration Unit laboratory (Jakarta), Centre for Research and Development of Food and Nutrition (Bogor), Veterinary Research Unit laboratory (Bogor), Department of Clinical Pathology laboratory, Department of Biochemistry and Biomoleculer laboratory, and Department of Pathology Anatomy laboratory Medical School University of Indonesia for their assistance in this study from the beginning to this study report, which is part of dissertation. To dr. Mohammad Sadikin, DSc; Prof. dr. Soemilah Sastroamidjojo, SpGz; Dr. Mien Karmini Mahmud, MS, APU; and Prof. dr. Mpu Kanoko Sastrosuwignyo, $\operatorname{SpPA}(\mathrm{K}), \mathrm{PhD}$ for reading and correcting the dissertation manuscript.

\section{References}

1. Suharyono, Firmansyah A, Wilharta AS. Aspek gastrointestinal pada tumbuh kembang anak. Dalam: Suharyono, penyunting. Esensial gastroenterologi anak. Jakarta: Balai Penerbit FKUI; 1995. p. 97-107.

2. Behrman RE, Shiono PH. Neonatal risk factors. In: Fanaroff AA, Martin RJ, editors. Neonatal-perinatal medicine: Disease of the fetus and infant. 6th ed. St Louis: Mosby; 1997. p. 3-12.
3. Prindull G, Manzar A. The ontogeny of the gut mucosal immune system and the susceptibility to infection in infants of developing countries. Eur J Pediatr 1993;152:786-92.

4. Brundtland GH. Women of South East Asia: A health profile. Regional publications SEARO No. 34; 2000.

5. Ahmed F. Novel foods across the lifespan, from infant formula to impact on aging. Asia Pacific J Clin Nutr 2002;11(S6);S112-6.

6. Buchmiller-Crair TL, Gregg JP, River FA, Choi RS, Diamond JM, Fonkalsrud EW. Delayed disaccharidase development in a rabbit model of intrauterine growth retardation. Pediat Res 2001;50:520-4.

7. Boersma B, Wit JM. Catch-up growth. Endocrin reviews 1997;18:646-61. Available at: http://www.edrv. endojournals.org/cgi/content/full/18/5/646.

8. Cook GC, Lee FD. The jejunum after kwashiorkhor. Lancet 1966;1263-7.

9. Young CM, Lee PC, Lebenthal E. Maternal dietary restriction during pregnancy and lactation: Effect on digestive organ development in suckling rats. Am J Clin Nutr 1987;46:36-40.

10. Firmansyah A. Pengaruh malnutrisi terhadap saluran cerna tikus putih: Perhatian khusus pada perkembangan morfologis, biokimia, dan fisiologi terutama kolon [disertasi]. Jakarta: Program Pascasarjana Universitas Indonesia;1992.

11. Nainggolan M. Experiment design: Perencanaan dan penggunaannya dalam praktek. Medan;1965.

12. Dahlqvist A. Method for assay of intestinal disaccharidases. Analyt Biochem 1964;7:18-25.

13. Lebenthal E, Nitzan M, Chrzanowksi BL, Krantz B. The effect of reduced maternofetal blood flow on the development of fetal pancreatic acinar and enzymes. Pediat Res1980;14:1356-9.

14. Shrader RE, Ferlatte MI, Zeman FJS. Early postnatal development of the intestine in progeny of proteindeprived rats. Bil Neonate 1977;31:181-98.

15. Firmansyah A, Suwandito L, Penn D, Lebenthal E. Pre and postnatal nutrient depriviation causes hypotrophic small intestinal and hypoplastic colonic mucosa. Am J Clin Nutr 1988;47:779.

16. Hatch TF, Lebenthal E, Bransi D, Krasner. The effect of early postnatal acquired malnutrition on intestinal growth, disaccharidases and enterokinase. J Nutr 1979;109:1874-9.

17. Rossi TM, Lee PC, Young CM, Lerner A, Lebenthal E. Effect of nutritional rehabilitation on the development 
Rustadi Sosrosumihardjo et al: Morphology and disaccharidase activity of small intestinal mucosa in malnourished rats

of intestinal brush-border disaccharidases of postnatally malnourished weanling rats. Int Pediatr Res 1983;20:793-7.

18. Butzner JD, Gall DG. Impact of refeeding on intestinal development and function in infant rabbits subjected to protein-energy malnutrition. Pediatr Res 1990;27: 245-51.

19. Jambunathan LR, Neuhoff D, Younoszai MK. Intestinal disaccharidases in malnourished infant rats. Am J Clin Nutr 1981;34:1879-84. 